\title{
Drying Poultry Manure for Pollution Potential Reduction and Production of Organic Fertilizer
}

\author{
A.E. Ghaly and M. Alhattab \\ Department of Process Engineering and Applied Science, \\ Dalhousie University, Halifax, Canada
}

Received 2013-03-26, Revised 2013-04-12; Accepted 2013-04-13

\begin{abstract}
Disposal and storage of raw poultry manure has become an environmental problem because of the associated air, water and soil pollution. Poultry manure begins to decompose immediately after excretion giving off ammonia which, in high concentrations, can have adverse effects on the health and productivity of birds as well as the health of the farm workers. Application to land is the most common way for utilizing poultry manure as a viable source of major plant nutrients and soil conditioner to improve soil tilth and reduce the problems associated with soil compaction. The aim of this study was to investigate the effects of drying depth and temperature on the nutritional profile of dried poultry manure and its suitability as a plant fertilizer. Drying temperature and manure depth had no significant effects on manure $\mathrm{pH}$, but the loss of ammonia during the drying process decreased the $\mathrm{pH}$ (from 8.4 to 6.4-6.7). Greater nitrogen losses (44-55\%) were observed at the deeper manure layer $(3 \mathrm{~cm})$ and the higher temperature $\left(60^{\circ} \mathrm{C}\right.$ ) which resulted in a reduction of $\mathrm{N}: \mathrm{P}: \mathrm{K}$ (from 4.58:1.29:1 to 2.07:1.30:12.57:1.28:1). Drying of poultry manure helped reduce the presence and offensiveness of odor by 65.3 and $69.3 \%$, respectively. Drying of poultry manure also achieved significant reductions in bacteria (65.6-99.8\%), yeast and mold (74.1-99.6\%) and E. coli (99.97\%). Dried poultry manure can be used as a fertilizer source for plants because of its high nitrogen, phosphorus and potassium contents which are essential for plant growth. Other elements (such as calcium, magnesium, sulfur, boron, copper, iron, manganese, molybdenum, cobalt and zinc) which are lacking in commercial fertilizer are also present in manure in significant amounts.
\end{abstract}

Keywords: Poultry Manure, Drying, Temperature, Depth, Moisture Content, pH, Odor, Microorganisms, Organic Fertilizer, NPK, Plant Nutrients

\section{INTRODUCTION}

Rearing of birds has grown from a side-line occupation into a commercial enterprise with single farms having thousands of birds. The current poultry industry is one of the largest and fastest growing sectors of livestock and poultry production in the world. The meat and egg production increased by $35 \%$ during the period of 2000-2008. The 2010 world flock is estimated to be over 18 billion birds with an estimated annual output of 22 million tonnes of manure (FAO, 2010). It is, therefore, necessary to find economically viable and environmentally acceptable ways of utilizing such large quantities of waste (Joshi and Devrajan, 2008; Jokela, 1992; Bittman et al., 2005).
Storage and disposal of raw poultry manure has become an environmental problem because of the associated air, water and soil pollution (Benali and Kudra, 2002). Poultry manure begins to decompose immediately after excretion giving off ammonia which, in high concentrations, can have adverse effects on the health and productivity of birds as well as the health of the farm workers (Pierson et al., 2001; Zhang and Lau, 2007; Amon et al., 2006). Manure is a source of odor caused by the activity of microorganisms in the manure and can also serve as a breeding ground for pathogenic microorganisms as well as a transmitting medium for diseases among the birds (Berry and Miller, 2005; Fares et al., 2005). Flies and other Corresponding Author: Abdel Ghaly, Department of Process Engineering and Applied Science, Dalhousie University, Halifax, Nova Scotia, Canada Tel: (902)494-6014, E-mail:abdel.ghaly@dal.ca. 
undesirable insects can breed on the manure leading to nuisance and health hazards (Lay et al., 2011; Axtell, 1999). It is, therefore, necessary to subject poultry manure to some treatments in order to improve its storage and handling and to minimize the risk of disease transmission and environmental pollution. Proper poultry manure management systems that will preserve the environment, contribute to both animal and human health and return a profit on investment to farmers, need to be developed.

Traditionally, land application has been the most common way of utilizing poultry manure as a viable source of major plant nutrients and soil conditioner to improve soil tilth and reduce the problems associated with soil compaction (Kelleher et al., 2002; Zhang and Lau, 2007; Wen et al., 2007; Tanabe et al., 1985; Chambers and Smith, 1992; Martin and McCann, 1998). However, environmental problems such as odor and pathogens may arise during and after land application of raw manure (Ghaly and Sihgh, 1991; Sims and Wolf, 1994; Risse et al., 2006; Rappert and Muller, 2005). Several solid-liquid separation techniques have been tried for poultry manure treatment before land application. These include: mechanical separation (Shirley and Butchbaker, 1975), filtration, stationary screens and thermal separation or drying (Ford and Flemming, 2002; Burton, 2007). Among these, drying is one of the most common method used to prevent environmental problems associated with application of raw manure.

Drying results in the removal of moisture from the manure thereby reducing the rate of deterioration from chemical and biological activities. It improves manure stickiness and hence makes manure handling easier (Ghaly and MacDonald, 2012a). Drying with heated air offers a number of advantages over unheated air drying including: higher rate of oxidation and pathogen destruction (Cummings and Jewell, 1977; Ghaly and MacDonald, 2012b). Drying with heated air can be carried out using a variety of heat sources such as solar energy, electricity, natural gas and other fossil fuels. However, solar energy offers many advantages over other energy sources: (a) it is available in abundance all year round and it is relatively cheap to collect and utilize (Hatem and Ghaly, 1994; Ghaly and MacDonald, 2012a) and (b) it has higher rate of oxidation, waste stabilization, odor control and pathogen destruction (Ludington and Sobel, 1977; McCaskey et al., 1985; Ghaly and MacDonald, 2012b).

The main aim of this study was to evaluate the effect of manure drying on suitability of dried manure as an organic fertilizer. The specific objectives were to (a) evaluate the drying behaviour of laying hen manure at temperatures in the range that can be achieved by solar energy $\left(40-60^{\circ} \mathrm{C}\right)$ and different depths of manure and (b) determine the changes in the properties of the manure due to the drying process as measured by its plant nutritional value, pathogens content and presence and offensiveness of odor.

\section{MATERIALS AND METHODS}

\subsection{Drying Trays}

Three sets of trays, each set consisting of three trays of the same dimensions, were constructed of galvanized steel and used for the drying of poultry manure. The trays have drying surface areas of $100 \mathrm{~cm}^{2}$ each. The depths of the trays were $1 \mathrm{~cm}, 2 \mathrm{~cm}$ and $3 \mathrm{~cm}$ for the sets 1,2 and 3 , respectively. Figure 1 shows the dimensions of a drying tray.

\subsection{Manure}

Poultry manure was obtained from a layers house on Archibald Farms located in Stewiack East, approximately $80 \mathrm{~km}$ from Halifax, Nova Scotia. The manure was collected under battery cages of a laying house accommodating approximately 50,000 hens. The manure collected was fresh and was not subjected to any treatment on the farm. It was then placed in clean plastic bags and transported to the Waste Management Laboratory at Dalhousie University, Halifax, Nova Scotia where it was stored at $-18^{\circ} \mathrm{C}$. Some characteristics of the poultry manure used in this study are presented in Table 1.

\subsection{Experimental Procedure}

The effects of three drying temperatures (40,50 and $60^{\circ} \mathrm{C}$ ) and three manure depths $(1,2$ and $3 \mathrm{~cm})$ on the manure drying rate, drying time, manure characteristics and plant nutritional value were investigated. Prior to placing the manure in the drying trays, it was removed from the freezer and allowed to thaw for 24 hours at room temperature $\left(22^{\circ} \mathrm{C}\right)$. The three sets of trays were weighed PM4600, Fisher Scientific, Montreal, Quebec). The trays were then filled to their respective depths with the manureand weighed.

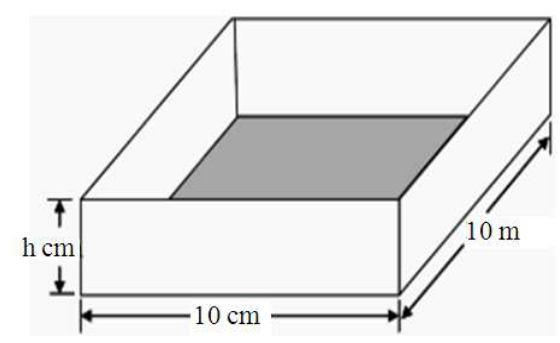

Fig. 1. The dimensions of the drying tray $(\mathrm{h}=1,2$ or $3 \mathrm{~cm})$ 
Table 1. Some characteristics of the poultry manure used in the study

\begin{tabular}{ll}
\hline Item & Measured value \\
\hline Moisture content & $78.4 \%$ \\
Density & $960 \mathrm{~kg} / \mathrm{m}^{3}$ \\
Total solids & $215520 \mathrm{mg} / \mathrm{L}$ \\
Volatile solids & $139770 \mathrm{mg} / \mathrm{L}$ \\
Ash & $75750 \mathrm{mg} / \mathrm{L}$ \\
Total chemical oxygen demand & $328500 \mathrm{mg} / \mathrm{L}$ \\
Soluble chemical oxygen demand & $130000 \mathrm{mg} / \mathrm{L}$ \\
Total kjeldahl nitrogen & $18960 \mathrm{mg} / \mathrm{L}$ \\
Ammonium nitrogen & $9470 \mathrm{mg} / \mathrm{L}$ \\
Calcium & $19760 \mathrm{mg} / \mathrm{L}$ \\
Phosphorous & $5590 \mathrm{mg} / \mathrm{L}$ \\
Potassium & $4140 \mathrm{mg} / \mathrm{L}$ \\
pH & 8.40 \\
\hline
\end{tabular}

They were then placed in a forced draft oven (Isotemp Oven Model 655F, Fisher Scientific, Montreal, Quebec) adjusted to the required temperature. The drying rate was monitored by determining the change in weight at $2 \mathrm{~h}$ time intervals, until there was no change in weight. The oven temperature was then readjusted to the next level and the same experimental procedure was followed. Three replications for each temperature-manure depth combination were carried out.

\subsection{Experimental Analyses}

The properties of the manure were determined before drying. These were $\mathrm{pH}$, moisture content, density, total solids and volatile solids, total and soluble chemical oxygen demand, total-Kjeldahl nitrogen, ammoniumnitrogen, phosphorus and potassium. The $\mathrm{pH}$, moisture content, total plate count, pathogens, odor and nutritional analyses were performed on the dried samples. The $\mathrm{pH}$ was measured using a $\mathrm{pH}$ meter (Model 808MP, Fisher Scientific, Montreal, Quebec) according to the procedure described in the Methods of Soil Analysis (ASA, 1982). The density, total solids and chemical oxygen demand analyses were performed in the biotechnology laboratory of Dalhousie University, Halifax, Nova Scotia according to the procedures described in the Standard Methods for Examination of Water and Wastewater (APHA, 1998). The total Kjeldahl and ammonium nitrogen analyses were performed using Kjeltic Auto Analyzer (Model 1030, Tecator, Högenäs, Sweeden) according to Kjeldahl method. The elemental analysis was performed at the Minerals Engineering center of Dalhousie University using flame atomic adsorption spectroscopy. The nutritional analysis was performed at Nova West Laboratory Ltd, Saulnierville, Nova Scotia, Canada. The moisture content and microbial analyses and the odor evaluation were performed as follows.

\subsubsection{Moisture Content}

The moisture content was determined using the oven drying method according to the procedure described in the ASAE Standards (ASAE, 1991). Samples of approximately $10 \mathrm{~g}$ were dried at $103^{\circ} \mathrm{C}$ for $24 \mathrm{~h}$ in a drying oven (Isotemp Oven Model 655F, Fisher Scientific, Montreal, Quebec) and the Moisture Content (MC) was calculated as follows Equation 1:

$\mathrm{MC}_{\mathrm{wb}}=\frac{(\text { Weight of wet samples }- \text { Weight of dry samples })}{\text { Weight of dry samples }} \times 100$

\subsubsection{Total Microbial Count}

The total plate count was employed to estimate the numbers of viable aerobic and facultative microorganisms based on the assumption that each viable cell will develop into a colony under the specific condition of incubation. The manure samples were collected in wide mouth sterilized containers. Each sample was diluted to insure that one of the final plates would have 30-300 colonies; as the number of colonies within this range would give the most accurate approximation of the microbial population. The initial dilution (1:10) was prepared by placing $1 \mathrm{~g}$ into a $10 \mathrm{~mL}$ dilution blank (physiological saline water). The bottle was shaken vigorously to obtain a uniform distribution of organisms. Further dilutions $\left(1: 10^{3}, 1: 10^{4}, 1: 10^{5}, 1: 10^{7}\right.$, $1: 10^{8}$ ) were made by pipeting measured aliquots into additional dilution blanks. Sterile petri dishes were first labeled (specimen and dilution). Then, each bottle was thoroughly shaken and $1 \mathrm{~mL}$ of appropriate dilution was pipetted into a petri dish. Samples from each dilution were plated in duplicate. Approximately $15 \mathrm{~mL}$ of the cooled melted medium (Standard Methods Agar, Tryptone Glucose Yeast Agar, Neogen Corporation, Lansing, Michigan) were poured into each petri dish. Immediately thereafter, the plate was gently rotated 6 times in each direction to distribute the inoculum throughout the medium. The plates were allowed to solidify and were incubated in the inverted position in an incubator (Model Number 2020, VWR International, Cornelius, Oregon) at $35-37^{\circ} \mathrm{C}$ for 48 hours. The plate that contained a number of colonies in the range of 30 300 was selected. An accurate count of these colonies was made by placing the plate on the platform of a colony counter (Cat.No.7-910, Fisher Scientific, Montreal, Quebec). This instrument facilitated the counting process since the colonies were illuminated and 
seen against a ruled background. The number of colonies counted on a plate multiplied by the dilution of the specimen which the plate represents was equal to the cell count per milliliter of the specimen.

\subsubsection{Microbial and Insect Analyses}

The following analyses were also performed on raw dried manure samples: (a) yeast and mold enumeration (b) E. Coli estimation and (c) Salmonellae examination. These analyses were performed at Nova Scotia Research Foundation Corporation, Dartmouth, Canada.

\subsubsection{Odor}

A specially developed organoleptic test for measurement of odor from animal waste was used to measure the presence and offensiveness of odor in both the raw and dried poultry manures. This method was chosen because of the complex nature of manure odor which is best judged by the human nose. In this test, a scale of $0-10$ was utilized to rate the odor as to its presence and offensiveness. No odor was 0 and very strong odor was 10 . A similar scale of no offensive odor (0) and very offensive odor (10) was used. The intermediate numbers 1-9 are described in the Score Sheet (Figure 2), which was used by the panel members to rate the samples $(50 \mathrm{~g})$ placed before them in 125 Erlenmeyer flasks. They were asked to rate the contents of the flasks according to the scale 0-10. The lower limit (0) was assigned to distilled water, whereas the upper limit (10) was assigned to fresh poultry manure. The odor testing panel consisted of technician, graduate and undergraduate students and faculty. The size of the panel was 10 members. Each panel member was asked to rate the samples as to the presence of odor and the odor offensiveness according to the 0-10 scale and to describe the odor on the data sheet.

\section{RESULTS AND DISCUSSION}

\subsection{Drying Process}

The data on the drying time, moisture content and drying effectiveness at various manure depths and drying temperatures are presented in Table 2. The parameter "drying effectiveness" was defined in this study as the time needed to drive off $1 \mathrm{~g}$ of moisture from the manure. The results indicated that the $1 \mathrm{~cm}$ deep manure layer dried the fastest at all temperatures, followed by the $2 \mathrm{~cm}$ deep layer and the $3 \mathrm{~cm}$ deep manure layer.

\section{ODOR EVALUATION DATA SHEET}

\begin{tabular}{|c|c|c|c|}
\hline \multicolumn{4}{|c|}{$\begin{array}{l}\text { A. Rate the samples to the presence of odor and the odor } \\
\text { as to offensiveness according to the following scale us- } \\
\text { ing samples "0" as having } 0 \text { rating and samples "10" as } \\
\text { having } 10 \text { rating. }\end{array}$} \\
\hline \multicolumn{2}{|c|}{ Presence } & \multicolumn{2}{|l|}{ Offensiveness } \\
\hline No odor & 0 & No offensive odor & 0 \\
\hline Very faint & $1-2$ & Very faint offensive odor & $1-2$ \\
\hline Faint & $3-4$ & Faint offensive odor & $3-4$ \\
\hline Definite & $5-7$ & Definite offensive odor & $5-7$ \\
\hline Strong & $8-9$ & Strong offensive odor & $8-9$ \\
\hline Very strong & 10 & Very strong offensive odor & 10 \\
\hline
\end{tabular}

B. Describe the odor of each sample by giving an appropriate descriptive term. Possible terms that might be used are given in the list below or you may use a term of your choice which you feel properly describes the odor.

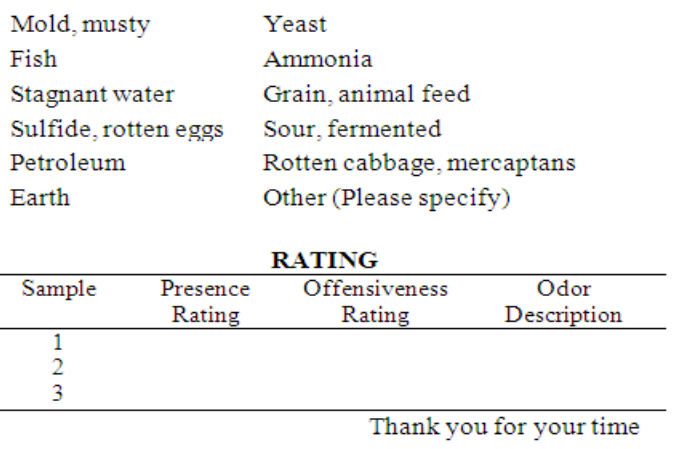

Fig. 2. Odor evaluation sheet

The thinner the manure layer, the lower the amount of moisture it contained and consequently the shorter the time duration required to drive off the moisture. The time required to dry the $2 \mathrm{~cm}$ deep manure layer was more than the time required to dry the $1 \mathrm{~cm}$ deep manure layer by about 106,100 , and $87 \%$, while the time required to dry the $3 \mathrm{~cm}$ deep manure layer was more than the time required to dry the $2 \mathrm{~cm}$ deep manure layer by 22,12 and $7 \%$ for 40,50 and $60^{\circ} \mathrm{C}$, respectively. The results showed that the difference in drying time between the shallower and deeper manure layers decreased as the drying temperature increased, However, when considering the drying effectiveness, the $3 \mathrm{~cm}$ deep manure layer was superior at all levels of temperature as less time was required to remove one gram of water from the manure. The results also showed that more time was required to remove one gram of water from the $2 \mathrm{~cm}$ deep manure layer than those required for the 1 and $3 \mathrm{~cm}$ deep manure layers at all temperatures as shown in Figure 3. 
Table 2. Drying time and drying effectiveness of poultry manure

\begin{tabular}{|c|c|c|c|c|c|c|}
\hline \multirow[b]{2}{*}{$\begin{array}{l}\text { Drying } \\
\text { Temperature }\left({ }^{\circ} \mathrm{C}\right)\end{array}$} & \multirow[b]{2}{*}{$\begin{array}{l}\text { Drying } \\
\text { Depth }(\mathrm{cm})\end{array}$} & \multirow[b]{2}{*}{$\begin{array}{l}\text { Drying } \\
\text { Time (h) }\end{array}$} & \multicolumn{4}{|c|}{ Weight(g) } \\
\hline & & & Initial & ------ & $\begin{array}{l}\text { Moisture } \\
\text { (g) }\end{array}$ & $\begin{array}{l}\text { Drying } \\
\text { Effectiveness }(\mathrm{h} / \mathrm{g})\end{array}$ \\
\hline \multirow[t]{3}{*}{40} & 1 & 55 & 125.95 & 27.15 & 98.80 & 0.56 \\
\hline & 2 & 106 & 224.70 & 48.43 & 176.27 & 0.60 \\
\hline & 3 & 120 & 312.72 & 67.41 & 245.31 & 0.50 \\
\hline \multirow[t]{3}{*}{50} & 1 & 44 & 129.16 & 27.84 & 101.32 & 0.43 \\
\hline & 2 & 84 & 226.21 & 48.71 & 177.50 & 0.47 \\
\hline & 3 & 90 & 314.28 & 67.74 & 246.54 & 0.37 \\
\hline \multirow[t]{3}{*}{60} & 1 & 28 & 127.18 & 27.41 & 99.77 & 0.28 \\
\hline & 2 & 52 & 227.86 & 49.11 & 178.75 & 0.29 \\
\hline & 3 & 60 & 322.57 & 69.52 & 253.05 & 0.24 \\
\hline
\end{tabular}

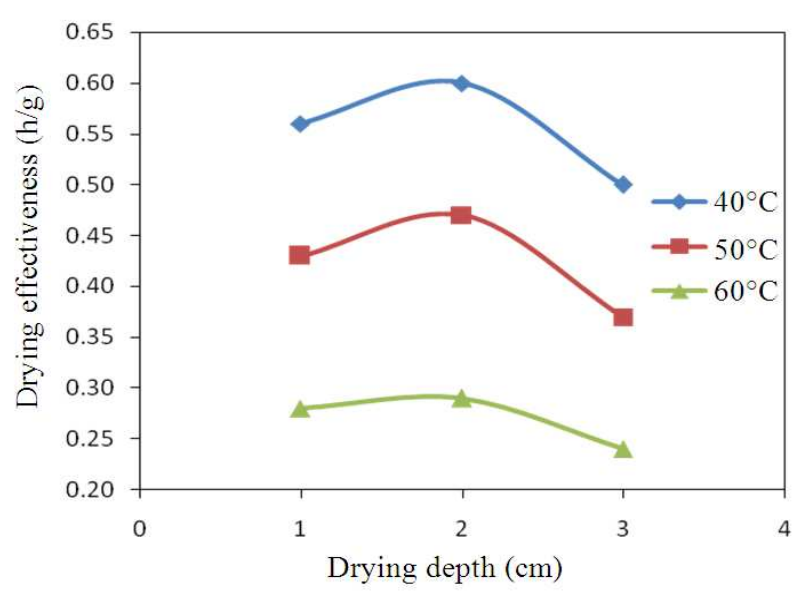

Fig. 3. Manure drying effectiveness

There is no information in the literature on this layer drying of manure and most of the work done was on grains, fruits and vegetables. Rao et al. (2007) investigated the thin layer drying of parbroiled paddy at depths between 5 and $20 \mathrm{~cm}$ and observed the fastest drying time at a depth of $5 \mathrm{~cm}$ and the optimum drying effectiveness at a depth in the range of $7-10 \mathrm{~cm}$. Nazghelichi et al. (2010) investigated the effect of bed depth on the drying of carrot cubes at 30,60 and $90 \mathrm{~mm}$ bed depth and found the optimum time and efficiency to be achieved at $30 \mathrm{~mm}$ depth. Maskan et al. (2002) investigated the effect of layer thickness, temperature and air velocity on the drying of the fruit leather and reported that the minimal drying layer thickness resulted in the fastest drying rate and effectiveness. Ertekin and Yaldiz (2004) studied the effect of drying eggplant slices with a $0.63,1.27$ and $2.54 \mathrm{~cm}$ thickness and found the fastest drying time with the $0.63 \mathrm{~cm}$ thick slices and the most effective drying with the $2.54 \mathrm{~cm}$ slices.

\subsection{Manure $\mathbf{p H}$}

The manure $\mathrm{pH}$ dropped from 8.4 to about 6.4-6.7 (Table 3) due to the loss of ammonia. In this study, the drying temperature and manure depth did not seem to have any significant effects on the $\mathrm{pH}$ of the dried manure. Gislason and Oelkers (2003) reported a pH range of 5.235.91 for basaltic glass drying over the temperature range of $30-100^{\circ} \mathrm{C}$. Himathongkham and Riemann (1999) noted that a decrease in ammonia content from $5.5 \mathrm{mgg}^{-1}$ to 0.75 $\mathrm{mg} \mathrm{g}^{-1}$ caused the $\mathrm{pH}$ to drop from 9.5 to 7.75 in fresh chicken manure. Sistani et al. (2001) reported a significant $\mathrm{pH}$ drop in broiler chicken litter upon drying at a temperature of $105^{\circ} \mathrm{C}$. Derikx et al. (1994) noted that during the drying of poultry, cattle and pig manure, all ammonia was volatilized when the $\mathrm{pH}$ was above 8 and the fatty acids evaporated when the $\mathrm{pH}$ was below 5 .

\subsection{Elemental Analyses}

The concentration of nitrogen, phosphorous and potassium in the dried poultry manure are shown in Table 3. Very small changes in the concentration of phosphorous and potassium occurred during the drying process. However, $44-55 \%$ of the nitrogen in the manure was lost depending on the depth of the manure layer and drying temperature, the deeper the layer and/or the higher the temperature the greater was the nitrogen loss. On average, $51 \%$ of total kjeldahl nitrogen (13\% organic nitrogen and $38 \%$ ammonium nitrogen) in the manure was lost during the drying process as shown in Table 4. As a result the initial N:P:K of 4.58:1.29:1 was reduced to $2.07: 1.30: 1-2.57: 1.28: 1$ due to loss of nitrogen, depending on the drying temperature and depth.

Ribeiro et al. (2001) reported an increase in nitrogen loss from 8.3 to $13.2 \%$ in poultry manure upon increases in temperature from 55 to $100^{\circ} \mathrm{C}$. Raviv et al. (1999) noted a reduction in nitrogen content in poultry manure upon exposure to temperatures above $65^{\circ} \mathrm{C}$. 
Table 3. pH and essential elements in raw and dried poultry manure

\begin{tabular}{lllllll}
\hline \multirow{2}{*}{$\begin{array}{l}\text { Drying } \\
\text { Temperature }\left({ }^{\circ} \mathrm{C}\right)\end{array}$} & Drying & - & Elements $(\% \mathrm{DB})$ & & \\
\hline 40 & Depth $(\mathrm{cm})$ & Nitrogen & Phosphorous & Potassium & NPK Ratioa & pH \\
& 1 & 4.92 & 2.46 & 1.91 & $2.57: 1.28: 1$ & 6.6 \\
& 2 & 4.63 & 2.45 & 1.90 & $2.43: 1.30: 1$ & 6.4 \\
50 & 3 & 4.48 & 2.46 & 1.91 & $2.35: 1.29: 1$ & 6.6 \\
& 1 & 4.45 & 2.45 & 1.90 & $2.34: 1.29: 1$ & 6.7 \\
60 & 2 & 4.35 & 2.45 & 1.89 & $2.30: 1.30: 1$ & 6.7 \\
& 3 & 4.23 & 2.46 & 1.90 & $2.20: 1.30: 1$ & 6.7 \\
& 1 & 4.16 & 2.45 & 1.89 & $2.10: 1.28: 1$ & 6.6 \\
Raw Manure & 2 & 3.99 & 2.44 & 1.90 & $2.07: 1.30: 1$ & 6.6 \\
\hline
\end{tabular}

Table 4. Nitrogen concentrations and losses

\begin{tabular}{|c|c|c|c|c|c|c|c|}
\hline \multirow{2}{*}{$\begin{array}{l}\text { Drying } \\
\text { Temperature }\left({ }^{\circ} \mathrm{C}\right)\end{array}$} & \multirow{2}{*}{$\begin{array}{l}\text { Drying Depth } \\
(\mathrm{cm})\end{array}$} & \multicolumn{3}{|c|}{ Nitrogen Content (mg/kg) } & \multicolumn{3}{|c|}{ Losses $(\%)$} \\
\hline & & $\mathrm{TKN}$ & Org-N & $\mathrm{Am}-\mathrm{N}$ & Total & Org-N & Am-N \\
\hline \multirow[t]{3}{*}{40} & 1 & 49350 & 36370 & 12980 & 19.73 & 12.31 & 7.42 \\
\hline & 2 & 46340 & 33450 & 12890 & 24.62 & 17.06 & 7.61 \\
\hline & 3 & 43810 & 32960 & 10850 & 28.74 & 17.86 & 10.88 \\
\hline \multirow[t]{3}{*}{50} & 1 & 44900 & 33920 & 10980 & 27.00 & 16.30 & 11.30 \\
\hline & 2 & 43490 & 32610 & 10880 & 29.26 & 18.43 & 10.83 \\
\hline & 3 & 41880 & 32060 & 9820 & 31.88 & 19.32 & 12.56 \\
\hline \multirow[t]{3}{*}{60} & 1 & 41280 & 32930 & 8350 & 32.86 & 17.91 & 14.95 \\
\hline & 2 & 39890 & 31600 & 8290 & 35.11 & 20.07 & 15.83 \\
\hline & 3 & 39260 & 30940 & 8220 & 36.30 & 21.15 & 15.15 \\
\hline Raw manure & & 61480 & 43940 & 17540 & - & - & - \\
\hline
\end{tabular}

Abdalla and Abu Bakar (2004) noted that an increase in drying temperature from $30^{\circ} \mathrm{C}$ to $70^{\circ} \mathrm{C}$ decreased the nitrogen content by $12-26 \%$ and $9-42 \%$ in maize and groundnut plant residues.

Researchers have noted that phosphorous content is affected by drying process (Ajiboye et al., 2004; Akinremi et al., 2003; Gerritse and Eksteen, 1978; Sistani et al. 2001). Sistani et al. (2001) noted a lower phosphorous content in broiler chicken manure as a result from freeze or oven drying at $105^{\circ} \mathrm{C}$. Akinremi et al. (2003) achieved the lowest concentrations of phosphorous in poultry, cattle and pig manure upon drying at $105^{\circ} \mathrm{C}$ as appose to freeze-dried and air-dried samples $\left(30^{\circ} \mathrm{C}\right)$. Chapuis-Lardy et al. (2004) noted lower concentrations of phosphorous in dried feces as appose to wet dairy feces. Tagoe et al. (2008) noted that poultry manure that has been carbonized at $500^{\circ} \mathrm{C}$ has a higher phosphorus content $(18.17 \mathrm{~g} / \mathrm{kg})$ available than in dried poultry manure $(4.47 \mathrm{~g} / \mathrm{kg})$.

Ghosh et al. (2004) reported nitrogen, phosphorous and potassium contents in poultry manure of 2.14, 1.09 and $1.23 \%$, respectively. Ayoola and Adeniyan (2006) noted nitrogen, phosphorous and potassium contents in poultry manure of $1.98,1.74$ and $2.00 \%$, respectively.

\subsection{Odor}

At the start of a new experiment, the odor given off near the oven during the drying process was noticeable. However, when the drying process progressed, the presence and offensiveness of the odor decreased with the time and the final product (dried manure) did not have any offensive odor. The result of the organoleptic test (Table 5) showed that both the presence and offensiveness of the odor in the dried poultry manure were reduced by 65.3 and $69.3 \%$ (as compared to that of the fresh poultry manure). The odor present in the dried manure was not offensive $(23.3 \%$ of the panel members described the odor as that of grain, $20 \%$ described it as a mold musty, $13.3 \%$ described it as ammonia, $13.3 \%$ described it as fermented, $6.7 \%$ described it as fish odor, $6.7 \%$ described it as yeast odor ad $6.7 \%$ described it as rotten eggs odor).

Lekasi et al. (2003) stated that air drying of animal manure reduces the smell. Ghaly and MacDonald (2012a) reported that drying of poultry manure over the temperature range of $40-60^{\circ}$ achieved reductions in odor intensity and offensiveness of 65 and $69 \%$, respectively. 
Table 5. Odor rating

\begin{tabular}{llr}
\hline Parameter & Dried & Raw \\
\hline Presence & $3.47 \pm 1.25$ & 10 \\
Offensiveness & $3.07 \pm 1.53$ & 10 \\
Description & & \\
Grain, Feed & 10 & - \\
Mold, Musty & 6 & - \\
Sour, Fermented & 4 & - \\
Yeast & 2 & - \\
Earth & 2 & - \\
Fish & 2 & - \\
Sulfide, Rotten Egg & 2 & 12 \\
Ammonia & 2 & 6 \\
Stagnant water & - & 5 \\
Rotten Cabbage Mercaptans & - & 7 \\
\hline
\end{tabular}

* Total number of observations-30

Nahm (2003) noted that the reductions in hydrogen sulphide and ammonia concentrations during drying reduced the of poultry manure.

\subsection{Microbial Count}

The results of the microbial analyses are shown in Table 6. Generally, high numbers of bacteria $\left(477 \times 10^{7}\right.$ manure) were found in the raw manure. The drying process reduced the number of bacteria by $65.62 \%$ $99.83 \%$ (from $477 \times 10^{7}$ to $164 \times 10^{7}-808 \times 10^{4}$ cells $/ g$ manure), the yeast and mold cells by $74.07 \%-99.63 \%$ (from 2700 cells/g manure to $700-<10$ cells/g manure) and the number of $E$. coli by $99.97 \%$ (from 21,986,666 to $6263-<10$ cells/g manure). Salmonellae was detected in the raw manure and the dried manure samples collected from the $3 \mathrm{~cm}$ deep manure layer after drying at $40^{\circ} \mathrm{C}$. The results indicated that the higher the drying temperature and/or the thinner the manure layer, the more destruction of microorganisms in the dried manure. The killing actions of heat appeared to be timetemperature dependent.

Several researchers reported that $90 \%$ of microorganisms in manure will be destroyed in a few days at temperatures in the range of $20-40^{\circ} \mathrm{C}$ and a few weeks at temperatures of $4-10^{\circ} \mathrm{C}$ (Himathongkham and Riemann, 1999; Placha et al., 2001; Hutchison et al., 2005). Larney et al. (2003) noted that a period of 7 days was necessary to eliminate Escherichia coli in beef cattle manure at temperatures in the range of $33.5-41.5^{\circ} \mathrm{C}$. Wang et al. (1996) reported that Escheriahia coli in bovine feces can survive 42-49, 49-56 and 63-70 days at temperatures of 37,22 and $5^{\circ} \mathrm{C}$, respectively. In this study, higher temperatures $\left(40-60^{\circ} \mathrm{C}\right)$ were used which resulted in less time (28-120 h) for elimination of microorganisms and lower nitrogen losses compared to other studies.

\subsection{Plant Nutritional Requirements}

Plants require essential nutrients for growth. These nutrients can be divided into macronutrients and micronutrients.

\subsubsection{Macroelements}

Macroelements are required by plants in relatively large amounts $(>100 \mathrm{mg} / \mathrm{kg}$ dry diet $)$ and include calcium $(\mathrm{Ca})$, Nitrogen $(\mathrm{N})$, Magnesium $(\mathrm{Mg})$, Phosphorus $(\mathrm{P})$, potassium (K) and Sulfur (S). These elements function in cellular metabolism, have important roles in osmoregulation and acid-base balance and serve as structural components of tissues (Brady and Weil, 1996; Ecosystem Restoration, 2004). The deficiency and toxicity symptoms of macroelements are listed in Table 7.

Calcium is an essential nutrient in plants which functions in structural components (protein) of plants cell wall and membranes (Marschner, 1995). It is required for growth of root and shoot tips (Evans, 2003). Calcium also plays a role in the plant cell division and elongation processes (Rudd and Franklin-Tang, 2001), membrane permeability and the maintenance of cellular integrity (Hepler, 2005). It reduces the toxicity of manganese and aluminium (Evans, 2003).

Nitrogen plays a major role in plant growth because it is a part of all amino acids. Amino acids are the building blocks of proteins and enzymes which play a role in biological processes. Nitrogen stimulates development, root growth and the uptake of nutrients (Brady and Weil, 1996). Plants require nitrogen in the forms of $\mathrm{NO}_{3}^{-}$and $\mathrm{NH}_{4}^{+}$(Glass and Siddiqi, 1995). Uptake of nitrogen is affected by the $\mathrm{pH}, \mathrm{NH}_{4}^{+}$uptake is depressed under acidic conditions (Rygiewicz et al., 1984) and $\mathrm{NO}_{3}^{-}$uptake is depressed under alkaline conditions (Aslam et al., 1995).

Magnesium functions in metabolic processes of plants. These processes include photophosphorylation, photosynthetic carbon dioxide fixation, chlorophyll formation, phloem loading, synthesis of proteins, reactive oxygen species generation and photooxidation in leaf tissues. Magnesium deficiencies result in growth and yield impairment (Cakmak and Yazici, 2010).

Phosphorus is essential for several plant functions including energy transfer, reproduction, optimum growth, photosynthesis, nutrient movement within the plant, transfer of genetic characteristics and the transformation of starches and sugars. Phosphorous uptake occurs in the form of orthophosphate. Plants require inorganic phosphate in order to export energy from the chloroplast by Adenosine Triphosphate (ATP) (Sultenfuss and Doyle, 1999). Phosphorous increases plant resistance to disease (Evans, 2003). 
Table 6. Average microbial count in raw and dried poultry manure

\begin{tabular}{llllll}
$\begin{array}{l}\text { Drying Temperature } \\
\left({ }^{\circ} \mathrm{C}\right)\end{array}$ & $\begin{array}{l}\text { Drying Depth } \\
(\mathrm{cm})\end{array}$ & $\begin{array}{l}\text { Bacteria } \\
\left(10^{4} \text { cells/g) }\right.\end{array}$ & $\begin{array}{l}\text { Yeast/Mold } \\
(\text { cells/g) }\end{array}$ & $\begin{array}{l}\text { E. Coli } \\
\left(10^{4} \text { cells/g) }\right.\end{array}$ & $\begin{array}{l}\text { Salmonellae } \\
(\text { preserve })\end{array}$ \\
\hline 40 & 1 & 55000 & 250 & 10 & ND \\
& 2 & 69000 & 370 & 20 & ND \\
50 & 3 & 75000 & 430 & 30 & PP \\
& 1 & 2100 & 170 & $<10$ & ND \\
60 & 2 & 2900 & 210 & 10 & ND \\
& 3 & 4100 & 310 & $<10$ & ND \\
& 1 & 440 & $<10$ & $<10$ & ND \\
\hline Raw Manure & 2 & 530 & $<10$ & $<10$ & ND \\
\hline
\end{tabular}

PP- Partially Detected

ND-Not Detected

Table 7.Macroelement deficiency and toxicity symptoms in plants (Evans, 2003)

\begin{tabular}{lll}
\hline Element & Deficiency symptoms & Toxicity symptoms \\
\hline Calcium (Ca) & Root tips often die & No visible symptoms \\
& Bud development is inhibited & \\
& Young leaves become distorted and small with \\
& irregular margins and necrotic or spotted areas & \\
\hline Nitrogen (N) & Plant growth is restricted & Color is dark green \\
& Lack of chlorophyll (older leaves) & Abundant foliage \\
& results in yellow colored leaves & Restricted growth of root system \\
\hline Magnesium (Mg) & Reduction in plant growth & Affects Ca uptake \\
& Puckering effect on leaf margins & Necrotic spots develop \\
& & Smaller veins turn brown \\
\hline Phosphorous (P) & Reduction in plant growth & Deficiency in Zn, Fe, or \\
& Dark green leaves & Cu micronutrients can result \\
& Distorted leaf shape & \\
& Stems are thin & \\
& Root growth is limited & \\
\hline Potassium (K) & Reduced plant growth & Deficiency in Mg, Zn, Mn or Fe \\
& Internodes are shortened & \\
& Older leaves can become chlorotic and burn & \\
& Necrotic spots & \\
& Lateral breaks are reduced and wilt readily & \\
& Root system is poorly developed & \\
Stalks are weak & Leaves become yellow & \\
\hline Sulfur (S) & Stems and roots are small, woody and hard & size and plant growth \\
\hline
\end{tabular}

Potassium is essential for good crop yield and quality as it plays various regulatory roles in the development of the plants. These roles include enzyme activation, stomatal activity (water use), photosynthesis, transport of sugars, synthesis of starch and proteins and in nutrient and water transport (Van Brunt and Sultenfuss, 1998). It also helps overcome drought conditions, improves winter hardiness and increases resistance to diseases (Evans, 2003).

Sulfur is present in two major amino acids known as cysteine and methionine which are essential for plants primary and secondary metabolism (Droux, 2004). Sulfur is an essential compound in the vitamin thiamine which has been implicated to respond to DNA damage and pathogen attack in plants (Raschke et al., 2007).

\subsubsection{Microelements}

Microelements are required by plants in trace amounts ( $<100 \mathrm{mg} / \mathrm{kg}$ dry diet) and include boron (B), copper $(\mathrm{Cu})$, iron $(\mathrm{Fe})$, manganese $(\mathrm{Mn})$, molybdenum (Mo), Chlorine (Cl) and zinc ( $\mathrm{Zn})$ (Ronan, 2007). 
Table 8. Microelement deficiency and toxicity symptoms in plants (Evans, 2003)

\begin{tabular}{|c|c|c|}
\hline Element & Deficiency symptoms & Toxicity symptoms \\
\hline Boron (B) & $\begin{array}{l}\text { Breakdown (internal) of fruit or vegetables } \\
\text { Failure in normal root tip elongation } \\
\text { Leaves become thick, chlorotic and leathery } \\
\text { Disintegration of internal tissues }\end{array}$ & $\begin{array}{l}\text { Development of necrotic spots } \\
\text { on tips and edges of leaves } \\
\text { Plants become damaged }\end{array}$ \\
\hline Copper $(\mathrm{Cu})$ & $\begin{array}{l}\text { Young plants become dark } \\
\text { green, twisted or misshapen } \\
\text { Interveinal chlorosis (young leaves) }\end{array}$ & $\begin{array}{l}\text { Result in Fe deficiency } \\
\text { Reduced branching and thickening } \\
\text { Abnormal darkening of rootlets }\end{array}$ \\
\hline Iron $(\mathrm{Fe})$ & Young tissue interveinal chlorosis & Not evident in natural conditions \\
\hline Manganese (Mn) & $\begin{array}{l}\text { Interveinal chlorosis } \\
\text { Necrotic lesions and shedding of leafs } \\
\text { Chloroplast lamellae is disorganized }\end{array}$ & $\begin{array}{l}\text { Results in chlorosis } \\
\text { Uneven distribution of chlorophyll } \\
\text { Reduction in plant growth }\end{array}$ \\
\hline Molybdenum (Mo) & $\begin{array}{l}\text { Older leafs interveinal chlorosis } \\
\text { Cupping or marginal scorching of leaves }\end{array}$ & Rarely observed \\
\hline Chlorine $(\mathrm{Cl})$ & $\begin{array}{l}\text { Wilted leaves become necrotic and chlorotic and } \\
\text { eventually become a bronze color }\end{array}$ & $\begin{array}{l}\text { Leaf burn } \\
\text { Reduction in leaf size and growth rate }\end{array}$ \\
\hline Zinc (Zn) & $\begin{array}{l}\text { Leaf size reduction and internode length } \\
\text { Distorted or puckered leaf margins }\end{array}$ & Results in production of iron chlorosis \\
\hline
\end{tabular}

Microelements are involved in the regulation of cellular metabolism and are required for proper growth and development. Plant deficiency and toxicity symptoms of microelement are listed in Table 8.

Boron is an essential micronutrient in plants which functions in the synthesis of protein, flowering set increase, plant maturity, water retention and formation of plant hormones. It also affects the carbohydrate and nitrogen metabolism process (Ronan, 2007; Dick, 2010; Blevins and Lukaszewski, 1998).

Copper in plants possess numerous functional characteristics such as activation of enzymes, photosynthesis, reproductive phase and respiratory enzymes. Copper also plays a role in chlorophyll production(indirectly), increases the content of sugar present in plants, increases color intensity and improves the flavours in fruits and vegetables (Ronan, 2007; Rehm and Schmitt, 2009).

Iron in plants is responsible for photosynthesis and respiration processes and functions in enzyme mechanism which is responsible for the operation of the respiratory system. It also promotes chlorophyll formation, cell division and cell growth (Connolly and Guerinot, 2002; Ronan, 2007).

Manganese is the predominant element in organic acid metabolism of plants. It plays a role in some of the important enzymes in plants which are involved in enzyme synthesis and respiration. It works as an activator of enzymes that are involved in oxidation/reduction and hydrolysis reactions. It also works to activate the reduction process of hydroxylamine and nitrite to ammonia (Ronan, 2007; Spectrum Analytic Inc., 2012a; Millaleo et al., 2010).

Molybdenum is an essential component of enzymes which is used to carry out redox reactions. Molybdenum requiring enzymes include those that work in nitrate reduction, aldehyde oxidation and xanthine dehydrogenase. Molybdenum is also essential for plant growth (Ronan, 2007; Kaiser et al., 2005; Uchida, 2000).

Chlorine activates the enzyme which releases oxygen during photosynthesis, from water. It is important in drought resistance (stomata gate cells aperture) because chlorine regulates the growth of the cells and the turgor pressure. Chlorine is also the counter ion to the cations (positively charged ions) in the cell (Ronan, 2007; Uchida, 2000).

Zinc is responsible for the formation of auxin (growth hormones). It also plays a role in external elongation, protein synthesis, consumption and transformation of carbohydrates, stimulates maturity and the formation ofseed and grains (Ronan, 2007; Broadley et al., 2007; Waters and Sankaran, 2011). 
Table 9. Plant tissue nutrient sufficiency (Vitosh et al., 1994)

\begin{tabular}{lllll}
\hline Element & Corn & Wheat & Soybeans & Potato \\
\hline Macronutrients (\%) & & & & \\
Nitrogen (N) & $2.76-3.50$ & $2.59-3.00$ & $4.26-5.50$ & $2.50-4.00$ \\
Phosphorus (P) & $0.25-0.50$ & $0.21-0.50$ & $0.26-0.50$ & $0.18-0.22$ \\
Potassium (K) & $1.71-2.50$ & $1.51-3.00$ & $1.71-2.50$ & $6.00-9.00$ \\
Calcium (Ca) & $0.21-1.00$ & $0.21-1.00$ & $0.36-2.00$ & $0.36-0.50$ \\
Magnesium (Mg) & $0.16-0.60$ & $0.16-1.00$ & $0.26-1.00$ & $0.17-0.22$ \\
Sulfur (S) & $0.16-0.50$ & $0.20-0.40$ & $0.21-0.40$ & $0.21-0.50$ \\
Micronutrients (ppm) & & & $21-100$ & $30-200$ \\
Manganese (Mn) & $20-150$ & $16-200$ & $51-350$ & $30-300$ \\
Iron (Fe) & $21-250$ & $11-300$ & $21-55$ & $15-40$ \\
Boron (B) & $4-25$ & $6-40$ & $10-30$ & $7-30$ \\
Copper (Cu) & $6-20$ & $6-50$ & $21-50$ & $30-100$ \\
Zinc (Zn) & $20-70$ & $21-70$ & $1.0-5.0$ & $0.5-4.0$ \\
Molybdenum (Mo) & $0.1-2.0$ & $0.03-5.0$ &
\end{tabular}

\subsection{Plant Nutritional Value of Dried Poultry Manure}

The concentration range of nutrient requirement in plant tissue for sufficient growth is listed in Table 9.

Plant tissues with values lower than the given range are nutrient deficient and plants with values higher than the sufficiency range are toxic. The plant symptoms caused by deficiency and toxicity are listed in Table 7 and 8. Nutrient deficiency in plants can be fixed by application of fertilizer to the soil. Toxicity can be avoided by applying less frequently or applying lower amounts (Vitosh et al., 1994).

Numerous studies performed on poultry manure illustrated that poultry manure exerted a positive influence on crop production and improved the physical properties of soil (Guisquiani et al., 1995; Tam and Wong, 1995; McConnell et al., 1993). Zhou et al. (2005) studied the effect of different amounts of copper and zinc (present in poultry manure) on the growth of radish and pakchoi and concluded that the manure improved the growth of both plants and that the presence of the heavy metals in the manure did not cause acute toxicity to the plants. Sturgeon (2008) and Tewolde et al. (2005) reported that plant fertilized with broiler littler had greater concentrations of potassium in tissues then those receiving commercial fertilizer, but no harm on plants was observed. Ghosh et al. (2004) reported that sorghum responded better to poultry manure than farmyard manure as the fertilizer. Ayoola and Adeniyan (2006) reported of poultry manure increasing grain yield from $0.85-0.95 \mathrm{t} / \mathrm{ha}$ to $2.04-2.19 \mathrm{t} / \mathrm{ha}$.

The nutrient requirement by plants for growth and the nutritional composition of poultry manure are listed in Table 10. Organic fertilizers are always applied on the basis of nitrogen required by plants. Poultry manure can be used as fertilizer for plants because of its high nitrogen, phosphorous and potassium content. For example the corn crop requires $2520-3089 \mathrm{~kg}$ of manure per acre to meet the nitrogen requirement $(62-76 \mathrm{~kg} / \mathrm{acre})$ for growth. This would also supply $0.86,3.83,560,110,8.48,4.66,22.4$, $2.11,6.20,93.0,106,0.28$ and $10.2 \%$ of the required calcium, magnesium, phosphorous, potassium, sulfur, boron, copper, iron, manganese, molybdenum, chlorine, cobalt and zinc, respectively. Crops have a high phosphorous tolerance level and thus excess phosphorous (460 \%) will not harm the corn (Daniels, 1998). Also, the excess in potassium (10\%) and chlorine $(6 \%)$ nutrients are not significant. The deficiencies in calcium, magnesium, sulfur, boron, copper, iron, manganese, molybdenum, cobalt and zinc will be provided by the soil nutrients (Liu et al., 2000; Vitosh et al., 1994; McKenzie, 1992). Most commercial fertilizers supply nitrogen, phosphorus and potassium and do not have significant amounts of macro and micronutrients (McCauley, 2003; Finn and White, 1966).

\section{CONCLUSION}

Thin layer $(1-3 \mathrm{~cm})$ drying of poultry manure was effective at temperatures within the range provided by solar heaters $\left(40-60^{\circ} \mathrm{C}\right)$. The temperature and manure depth had no significant effects on the dried manure $\mathrm{pH}$. The loss of ammonia from manure resulted in a drop in the $\mathrm{pH}$ from the initial value of 8.4 to finial values in the range of 6.4-6.7. Greater nitrogen losses (44-55 \%) were observed at the deeper manure layer and higher temperature which resulted in a reduction in $\mathrm{N}: \mathrm{P}: \mathrm{K}$ from the initial value of $4.58: 1.29: 1$ to final values in the range 2.07:1.30:1-2.57:1.28:1. 
A.E. Ghaly and M. Alhattab / American Journal of Environmental Science 9 (2): 88-102, 2013

Table 10. Nutritional composition of dried poultry manure and plant nutrient requirement

\begin{tabular}{|c|c|c|c|c|c|}
\hline \multirow[b]{2}{*}{ Nutrient } & \multirow{2}{*}{$\begin{array}{l}\text { Dried } \\
\text { Poultry } \\
\text { Manure }\end{array}$} & \multicolumn{4}{|c|}{ Plant Requirement (kg/Acre) } \\
\hline & & Corn $^{\mathrm{a}}$ & Wheat ${ }^{b, c}$ & Potato $^{\mathrm{d}}$ & Soybean ${ }^{\mathrm{e}, \mathrm{c}}$ \\
\hline \multicolumn{6}{|c|}{ Macroelements (mg/kg) } \\
\hline Calcium & 42 & 13.6 & $23-68$ & 28 & $5-75$ \\
\hline Nitrogen & 24600 & $62-76$ & 39 & $90.8-109$ & $13.6-224$ \\
\hline Magnesium & 180 & 13.2 & 27 & 18 & $1.8-25$ \\
\hline Phosphorus & 24500 & $11-13.5$ & $18-23$ & $11-16$ & $1.2-21.9$ \\
\hline Potassium & 19000 & $43.7-53.1$ & 29 & $127-145$ & $10.2-150$ \\
\hline Sulfur & 200 & $5.9-7.3$ & 4.5 & $8-11$ & $0.91-13$ \\
\hline \multicolumn{6}{|c|}{ Mircoelements (mg/kg) } \\
\hline Boron & 1 & 0.06 & 0.03 & 0.08 & 0.04 \\
\hline Copper & 4 & 0.05 & $<0.05$ & 0.04 & 0.05 \\
\hline Iron & 4 & 0.53 & 0.28 & 0.8 & 2.87 \\
\hline Manganese & 4 & 0.18 & 0.20 & 0.4 & 0.46 \\
\hline Molybdenum & 1 & 0.003 & $<0.5$ & 0.002 & $<0.5$ \\
\hline Chlorine & 190 & 0.5 & 3.2 & 4.54 & 0.5 \\
\hline Cobalt & 0.5 & $<0.5$ & $<0.5$ & $<0.5$ & $<0.5$ \\
\hline Zinc & 4 & 0.11 & 0.12 & 0.05 & 0.34 \\
\hline $\mathrm{N}: \mathrm{P}: \mathrm{K}$ & $1.3: 1.28: 1$ & $1.4: 0.25: 1$ & $1.3: 0.7: 1$ & $0.7: 0.1: 1$ & $1.5: 0.15: 1$ \\
\hline
\end{tabular}

(a) Bundy (1998)

(b) McKenzie (1992)

(c) Bierman and Rosen (2005)

(d) Hopkins et al. (2003)

(e) Spectrum Analytic Inc. (2012b)

Drying of poultry manure helped reduce the presence and offensiveness of odor by 65.3 and $69.3 \%$, respectively. Drying of poultry manure also achieved a reduction in bacteria (65.6-99.8\%), yeast and mold (74.1-99.6\%) and E. coli $(99.97 \%)$. Dried poultry manure can be used as a fertilizer source for plants because of its high nitrogen, phosphorus and potassium contents which are essential for plant growth. Other elements (such as calcium, magnesium, sulfur, boron, copper, iron, manganese, molybdenum, cobalt and zinc) which are lacking in commercial fertilizer are also present in poultry manure in significant amounts.

\section{ACKNOWLEDGEMENT}

This research was funded by the Natural Science and Engineering Research Council (NSERC) of Canada.

\section{REFERENCES}

Abdalla, M.A. and R. Abu Bakar, 2004. The effect of drying temperature on nitrogen mineralization form above and below ground crop residues. University Khartoum J. Agricultural. Sci., 12: 47-65.

Ajiboye, B., O.O. Akinremi and G.J. Racz, 2004. Laboratory characterization of phosphorus in fresh and oven-dried organic amendments. J. Environmental Quality, 33: 1062-1069. PMID: 15224945
Akinremi, O.O., N. Armisen, M.A. Kashem and H.H. Janzen, 2003. Evaluation of analytical methods for total phosphorus in organic amendments. Communi. Soil Sci. Plant Analysis, 34: 2981-2991. DOI: 10.1081/CSS-120025220

Amon, B., V. Kryvoruchko, T. Amon and S. Zechmeister-Boltenstern, 2006. Methane, nitrous oxide and ammonia emissions during storage and after application of dairy cattle slurry and influence of slurry treatment. Agricul. Ecosystems Environment, 112: 153-162. DOI: 10.1016/j.agee.2005.08.030

APHA, 1998. Standard methods for the Examination of Water and Wastewater. 20th Edn., American Public Health Association, Washington, D.C. ISBN: 087553-175-X.

ASA, 1982. Methods of soil analysis part I: physical and mineralogical methods. Second Edn., (Klute- editor), American Society of Argonomy, Inc, Madison, Wisconsin. ISBN: 0891188118.

ASAE, 1991. Standards American Society of Agricultural Engineering, Saint Joseph, Michigan. ISBN: 8755187.

Aslam, M., R.L. Travis and R.C. Huffaker, 1995. Effect of $\mathrm{pH}$ and calcium on short-term $\mathrm{NO}^{3-}$ fluxes in roots of barley seedlings. Plant Physiol., 108: 727-734. PMID: 11536695 
Axtell, R.C., 1999. Poultry integrated pest management: Status and future. Integrated Pest Manage. Rev., 4: 53-73.

Ayoola, O.T. and O.N. Adeniyan, 2006. Influence of poultry manure and NPK fertilizer on yield and yield components of crops under different cropping systems in south west Nigeria. African J. Biotechnol., 5: 1386-1392.

Benali, M. and T. Kudra, 2002. Thermal dewatering of diluted organic suspensions: Process mechanism and drying kinetics. Drying Technol., 20: 935-951. DOI: 10.1081/DRT-120003770

Berry, E.D. and D.N. Miller, 2005. Cattle feedlot soil moisture and manure content: II. impact on Escherichia coli O157. J. Environmental Quality, 34: 656-663. PMID: 1575811

Bierman, P.M. and C.J. Rosen, 2005. Nutrient cycling and maintaining soil fertility in fruit and vegetable crop systems. University of Minnesota, Minneapolis, Minnesota.

Bittman, S., T.A. Forge and C.G. Kowalenko, 2005. Responses of the bacterial and fungal biomass in a grassland soil to multi-year applications of dairy manure slurry and fertilizer. Soil Biol. Biochemi., 37: 613-523. DOI: 10.1016/j.soilbio.2004.07.038

Blevins, D.G. and K.M. Lukaszewski, 1998. Boron in plant structure and function. Annual Rev. Plant Physiol. Plant Molecular Biol., 49: 481-500. PMID: 15012243

Brady, N.C. and R.R. Weil, 1996. The nature and properties of soils. 1st Edn., Prentice-Hall, Upper Saddle River, New Jersey, ISBN-10: 0132431890, pp: 740 .

Broadley, M.R., P.J. White, J.P. Hammond, I. Zelko and A. Lux, 2007. Zinc in plants. New Phytologist., 173: 677-702. PMID: 17286818

Bundy, L.G., 1998. Corn fertilization. University of Wisconsin-Madison, Madison, Wisconsin.

Burton, C.H., 2007. The potential contribution of separation technologies to the management of livestock manure. Livestock Sci., 112: 208-202. DOI: 10.1016/j.livsci.2007.09.004

Cakmak, I. and A.M. Yazici, 2010. Magnesium: A forgotten element in crop production. Better Crops, 94: 23-25.

Chambers, B.J. and K.A. Smith, 1992. Soil mineral nitrogen arising from organic manure application. Aspects Applied Biol., 30: 135-143.

Chapuis-Lardy, L., J. Fiorini, J.D. Toth and Z. Dou, 2004. Phosphorus concentration and solubility in dairy feces: Variability and affecting factors. J. Dairy Sci., 87: 4334-4341. PMID: 15545398
Connolly, E.L. and M.L. Guerinot, 2002. Iron stress in plants. Genome Biol., 3: 1024.1-1024.4.

Cummings, R.J. and W.J. Jewell, 1977. Thermophilic aerobic digestion of dairy waste. In: Food, Fertilizer and Agricultural Residues, Loehr, R.C. (Ed.), Ann Arbor Science Publishers Inc., Michigan. Illinois.

Daniels, M., 1998. Soil phosphorus levels: Concerns and recommendations. Cooperative Extension Service, University of Arkansas.

Derikx, P.J.L., H.C. Willers and P.J.W. Ten Have, 1994. Effect of $\mathrm{pH}$ on the behaviour of volatile compounds in organic manures during dry-matter determination. Bioresou. Technol., 49: 41-45. DOI: 10.1016/09608524(94)90171-6

Dick, C., 2010. Low boron and excess iron, is there an interaction? Calcium Products, Iowa.

Droux, M., 2004. Sulfur assimilation and the role of sulfur in plant metabolism: A survey. Photosynthesis Res., 79: 331-348. DOI: 10.1023/B:PRES.0000017196.95499.11

Ecosystem Restoration, 2004. Analytical Methods. Montana State University Boseman.

Ertekin, C. and O. Yaldiz, 2004. Drying of eggplant and selection of a suitable thin layer drying model. J. Food Eng., 63: 349-359. DOI: 10.1016/j.jfoodeng.2003.08.007

Evans, E., 2003. Nutrient deficiency. NC State University, Raleigh, North Carolina.

FAO, 2010. Agricultural Handbook: Poultry Meat and Eggs. 1st Edn., FAO Investment Centre Division, Rome Italy.

Fares, F., A. Albalkhi, J. Dec, M.A. Bruns and J. Bollag, 2005. Physicochemical characteristics of animal and municipal wastes decomposed in arid soils. J. Environmental Quality, 34: 1392-1403. PMID: 15998862

Finn, R.F. and D.P. White, 1966. Commercial fertilizers increase growth in a yellow-poplar plantation. J. Forestry, 64: 809-810.

Ford, M. and R. Fleming, 2002. Mechanical solid-liquid separationof livestock manureliterature review. University of Guelph, Ridgetown College, Ridgetown, Ontario.

Gerritse, R.G. and R. Eksteen, 1978. Dissolved organic and inorganic phosphorus compounds in pig slurry: Effect of drying. J. Agricultural Sci., 90: 39-45. DOI: $10.1017 /$ S0021859600048577

Ghaly, A.E. and K.N. MacDonald, 2012a. Drying of poultry manure for use as animal feed. Am. J. Agricultural Biological Sci., 7: 239-254. DOI: 10.3844/ajabssp.2012.239.254 
Ghaly, A.E. and K.N. MacDonald, 2012b. An effective passive solar dryer for thin layer drying poultry manure. Am. J. Eng. Applied Sci., 5: 136-150. DOI: 10.3844/ajeassp.2012.136.150

Ghaly, A.E. and R. Singh, 1991. Laboratory evaluation of the pollution potential of land applied dairy manure. Waste Manag., 11: 307-318. DOI: 10.1016/0956053X(91)90077-I

Ghosh, P.K., P. Ramesh, K.K. Bandyopadhyay, A.K. Tripathi and K.M. Hati et al., 2004. Comparative effectiveness of cattle manure, poultry manure, phosphocompost and fertilizer-NPK on three cropping systems in vertisols of semi-arid tropics. I. Crop yields and system performance. Bioresou. Technol., 95: 77-83. DOI: 10.1016/j.biortech.2004.02.011

Gislason, S.R. and E.H. Oelkers, 2003. Mechanism, rates and consequences of basaltic glass dissolution: II. An experimental study of the dissolution rates of basaltic glass as a function of $\mathrm{pH}$ and temperature. Geochimica et Cosmochimica Acta, 67: 3817-3832. DOI: 10.1016/S0016-7037(03)00176-5

Glass, A.D.M. and M.Y. Siddiqi, 1995. Nitrogen absorption by plant roots. In: Nitrogen Nutrition in Higher Plants, Srivastava, H.S. and R.P. Singh, (Eds.), pp: 21-56.

Guisquiani, P.L., M. Pagliai, G. Gigliotti and A. Benetti, 1995. Urban waste compost: Effects on physical, chemical, and biochemical soil properties. J. Environmental Quality, 24: 175-182. DOI: $10.2134 /$ jeq1995.00472425002400010024x

Hatem, M.H. and A.E. Ghaly, 1994. Composting of municipal solid waste. Misr J. Agricultural Eng., 11: 548-558.

Hepler, P.K., 2005. Calcium: A central regulator of plant growth and development. Plant Cell, 17: 2142-2155. DOI: $10.1105 /$ tpc. 105.032508

Himathongkham, S. and H. Riemann, 1999. Destruction of Salmonella typhimurium, Escherichia coli O157:H7 and Listeria monocytogenes in chicken manure by drying and/or gassing with ammonia. FEMS Microbiol. Lett., 171: 179-182. PMID: 10077842

Hopkins, B.G., J.C. Stark, D.T. Westermann and J.W. Ellsworth, 2003. Nutrient management efficiency. nutrient management, potato production systems. University of Idaho, Moscow, Idaho, pp: 115-134.

Hutchison, M.L., L.D. Walters, T. Moore, D.J. Thomas and S.M. Avery, 2005. Fate of pathogens present in livestock wastes spread onto fescue plots. Applied Environmental Microbiol., 71: 691-696. PMID: 15691918
Jokela, W.E., 1992. Nitrogen fertilizer and dairy manure effects on corn yield and soil nitrate. Soil Sci. Society Am. J., 56: 148-154.

Joshi, V.K. and A. Devrajan, 2008. Ethanol recovery from solid state fermented apple pomace and evaluation of physico-chemical characteristics of the residue. Natural Product Radiance, 7: 127-132.

Kaiser, B.N., K.L. Gridley, J.N. Brady, T. Phillips and S.D. Tyerman, 2005. The role of molybdenum in agricultural plant production. Annals Botany, 96: 745-754. DOI: 10.1093/aob/mci226

Kelleher, B.P., J.J. Leahy, A.M. Henihan, T.F. O’Dwyer and D. Sutton et al., 2002. Advances in poultry litter disposal technology--a review. Bioresou. Technol., 82: 27-36. PMID: 12058828

Larney, F.J., L.J. Yanke, J.J. Miller and T.A. McAllister, 2003. Fate of coliform bacteria in composted beef cattle feedlot manure. J. Environmental Quality, 32: 1508-1515. DOI: $10.2134 /$ jeq2003.1508

Lay Jr., D.C., R.M. Fulton, P.Y. Hester, D.M. Karcher and J.B. Kjaer et al., 2011. Hen welfare in different housing systems. Poultry Sci., 90: 278-294. DOI: $10.3382 /$ ps.2010-00962

Lekasi, J.K., J.C. Tanner, S.K. Kimani and P.J.C. Harris, 2003. Cattle manure quality in maragua district, central kenya: Effect of management practices and development of simple methods of assessment. Agriculture, Ecosystems Environment, 94: 289-29. DOI: 10.1016/S0167-8809(02)00037-3

Liu, A., C. Hamel, R.I. Hamilton, B.L. Ma and D.L. Smith, 2000. Acquisition of $\mathrm{Cu}, \mathrm{Zn}, \mathrm{Mn}$ and $\mathrm{Fe}$ by mycorrhizal maize (Zea mays L.) grown in soil at different $\mathrm{P}$ and micronutrient levels. Mycorrhiza, 9: 331-336. DOI: 10.1007/s005720050277

Ludington, D.C. and A.T. Sobel, 1977. Storability of partially dried laying hen manure. Food, Fertilizer and Agricultural Residues, Produced by Cornell Agriculture Waste Management Conference, Loehr, R.C., (Ed.), Ann Arbor Science Publishers Inc. Michigan, Illinoise.

Marschner, H., 1995. Mineral nutrition of higher plants. 2nd Edn., Academic Press, London, ISBN-10: 0124735428, pp: 889.

Martin, S.A. and M.A. McCann, 1998. Microbiological survey of Georgia poultry litter. J. Applied Poultry Res., 7: 90-98.

Maskan, A., S. Kaya and M. Maskan, 2002. Hot air and sun drying of grape leather (pestil). J. Food Eng., 54: 81-88. DOI: 10.1016/S0260-8774(01)00188-1 
McCaskey, T. A., A.L. Sutton, E.P. Lincoln, D.C. Dobson and J.P. Fontenote, 1985. Safety aspects of feeding animal wastes. In: Agricultural Waste Utilization and Management, ASAE Publication, Michigan.

McCauley, A., 2003. Commercial fertilizers and soil amendments. Nutrient Management Module 10. Montana State University Extension, Bozeman, Montana.

McConnell, D.D., A. Shiralipour and W.H. Smith, 1993. Compost application improves soil properties. BioCycle, 34: 61-63.

McKenzie, R.H., 1992. Micronutrient requirements of crops. Agriculture and Rural Development, Edmonton, Alberta.

Millaleo, R., M. Reyes-Diaz, A.G. Ivanov, M.L. Mora and M. Alberdi, 2010. Manganese as essential and toxic element for plants: Transport, accumulation and resistance mechanisms. J. Soil Sci. Plant Nutrition, 10: 470-481. DOI: 10.4067/S071895162010000200008

Nahm, K.H., 2003. Evaluation of the nitrogen content in poultry manure. World's Poultry Sci. J., 59: 77-88.

Nazghelichi, T., M.H. Kianmehr and M. Aghbashlo, 2010. Thermodynamic analysis of fluidized bed drying of carrot cubes. Energy, 35: 4679-4684. DOI: 10.1016/j.energy.2010.09.036

Pierson, S.T., M.L. Cabrera, G.K. Evanylo, H.A. Kuykendall and C.S. Hovel and et al., 2001. Phosphorus and ammonium concentrations in surface runoff from grasslands fertilized with broiler litter. J. Environ. Quality, 30: 1784-1789. PMID: 11577887

Placha, I., J. Venglovsky, N. Sasakova and I.P. Svoboda, 2001. The effect of summer and winter seasons on the survival of Salmonella typhimurium and indicator micro-organisms during the storage of solid fraction of pig slurry. J. Applied Microbiol., 91: 1036-1043. PMID: 11851811

Rao, P.S., S. Bal and T.K. Goswami, 2007. Modelling and optimization of drying variables in thin layer drying of parboiled paddy. J. Food Eng., 78: 480487. DOI: 10.1016/j.jfoodeng.2005.10.019

Rappert, S. and R. Muller, 2005. Odor compounds in waste gas emissions from agricultural operations and food industries. Waste Manag., 25: 887-907. PMID: 16129591

Raschke, M., K. Burkle, N. Muller, A. Nunes-Nesi and A.R. Fernie et al., 2007. Vitamin B1 biosynthesis in plants requires the essential iron sulfur cluster protein, THIC. Proc. National Academy Sci. United States Am., 104: 19637-19642. PMID: 18048325
Raviv, M., S. Medina and Y. Shamir, 1999. Cocomposting-a method to improve results of poultry manure composting. Compost Sci. Utilization, 7: 70-73.

Rehm, G. and M. Schmitt, 2009. Copper for crop production. University of Minnesota. Minneapolis, Minnesota.

Ribeiro, A.M.L., A.M. Penz, T.K. Belay and R.G. Teeter, 2001. Comparison of different drying techniques for nitrogen analysis of poultry excreta, feces, and tissue. J. Applied Poultry Res., 10: 21-23.

Risse, L.M., M.L. Cabrera, A.J. Franzluebbers, J.W. Gaskin and J.E. Gilley et al., 2006. Land application of manure for beneficial reuse. Biol. Syst. Eng.

Ronan, E., 2007. Micro-elements in agriculture. Practical Hydroponics Greenhouses, 95: 39-48.

Rudd, J.J. and V.E. Franklin-Tong, 2001. Unravelling response-specificity in $\mathrm{Ca}^{2+}$ signalling pathways in plant cells. New Phytologist, 151: 7-33. DOI: 10.1046/j.1469-8137.2001.00173.x

Rygiewicz, P.T., C.S. Bledsoe and R.J. Zasoski, 1984. Effects of ectomycorrhizae and solution $\mathrm{pH}$ on $\left[{ }^{15} \mathrm{~N}\right]$ ammonium uptake by coniferous seedlings. Canadian J. Forest Res., 14: 885-892.

Shirley, R. and A. Butchbaker, 1975. A rotating conical screen separator for liquid solid separation of beef waste. Managing Livestock Wastes. Publication PROC 2-75. American Society of Agricultural Engineers (ASAE), St. Joseph, MI, USA.

Sims, J.T. and D.C. Wolf, 1994. Poultry waste management: Agricultural and environmental issues. Advances Agronomy, 52:2-72.

Sistani, K.R., D.M. Miles, D.E. Rowe, G.E. Brink and S.L. McGowen, 2001. Impact of drying method, dietary phosphorus levels, and methodology on phosphorus chemistry of broiler manure. Communications Soil Sci. Plant Analysis, 32: 27832793. DOI: $10.1081 / C S S-120000961$

Spectrum Analytic Inc., 2012a. Manganese basics. Spectrum Analytic Inc., Washington Court House, Ohio.

Spectrum Analytic Inc., 2012b. Soybean growth nutrient management. Spectrum Analytic Inc., Wahington Court House, Ohio.

Sturgeon, L.E., 2008. Fertilizer value of densified broiler litter. Auburn University, Auburn, Alabama.

Sultenfuss, J.H. and W.J. Doyle, 1999. Functions of phosphorous in plants. Better Crops, 83: 6-7.

Tagoe, S.O., T. Horiuchi and T. Matsui, 2008. Effects of carbonized and dried chicken manures on the growth, yield, and N content of soybean. Plant Soil, 306: 211220. DOI: $10.1007 / \mathrm{s} 11104-008-9573-9$ 
Tam, N.F.Y. and Y.S. Wong, 1995. Spent pig litter as fertilizer for growing vegetables. Bioresou. Technol., 53: 151-155. DOI: 10.1016/0960-8524(95)00074-O

Tanabe, Y., K. Tanaka and Z. Kato, 1985. Feeding poultry waste to chickens, swine and cattle. In: Agricultural Waste Utilization and Management, ASAE Publication, St. Joseph, Michigan, pp: 13-85.

Tewolde, H., K.R. Sistani and D.E. Rowe, 2005. Broiler litter as a sole nutrient source for cotton: nitrogen, phosphorus, potassium, calcium, and magnesium concentrations in plant parts. J. Plant Nutrition, 28: 605-619. DOI: 10.1081/PLN-200052633

Uchida, R., 2000. Essential nutrients for plant growth: nutrient functions and deficiency symptoms. In: Plant nutrient management in Hawaii soils, Silva, J.A. and R. Uchida, (Eds.), University of Hawaii, Manoa, pp: 31-55.

Van Brunt, J.M. and J.H. Sultenfuss, 1998. Functions of potassium in plants. Better Crops, 82: 4-5.

Vitosh, M.L., D.D. Warncke and R.E. Lucas, 1994. Secondary and micronutrients for vegetables and field crops. Michigan State University Extension, Lansing, Michigan.
Wang, G., T. Zhao and M.P. Doyle, 1996. Fate of enterohemorrhagic Escherichia coli O157:H7 in bovine feces. Applied Environmental Microbiol., 62: 2567-2570.

Waters, B.M. and R.P. Sankaran, 2011. Moving micronutrients from the soil to the seeds: Genes and physiological processes from a biofortification perspective. Plant Sci., 180: 562-574. DOI: 10.1016/j.plantsci.2010.12.003

Wen, B.P., A. Aydin, N.S. Duzgoren-Aydin, Y.R. Li and H.Y. Chen et al., 2007. Residual strength of slip zones of large landslides in the Three Gorges area, China. Eng. Geol., 93: 82-98. DOI: 10.1016/j.enggeo.2007.05.006

Zhang, W. and A. Lau, 2007. Reducing ammonia emission from poultry manure composting via struvite formation. J. Chemi. Technol. Biotechnol., 82:598-602. DOI: $10.1002 /$ jctb.1701

Zhou, D., X. Hao, Y. Wang, Y. Dong and L. Cang, 2005. Copper and $\mathrm{Zn}$ uptake by radish and pakchoi as affected by application of livestock and poultry manures. Chemosphere, 59: 167-175. 